\title{
ANALISIS STABILITAS LERENG AKIBAT BEBAN GEMPA 4,9 SR PADA KASUS LONGSORAN JALAN BANDUNG-TASIK KM. 48 KABUPATEN GARUT
}

\author{
Aditia Febriansya $^{1}$, Andri Krisnandi Somantri ${ }^{1 *}$, Azwar Kays Kamal ${ }^{1}$, \\ Salma Fadhilah Suryadi ${ }^{1}$, Alman Rahadiansyah Willianto ${ }^{1}$ \\ ${ }^{1}$ Jurusan Teknik Sipil, Politeknik Negeri Bandung, Bandung 40012 \\ *E-mail Penulis Korespondensi: andri_krisnandi@polban.ac.id
}

\begin{abstract}
ABSTRAK
Longsor yang terjadi pada lahan Perumahan Cijolang, Kecamatan Limbangan, Kabupaten Garut setelah terjadinya gempa 4,9 SR mengakibatkan terganggunya lalu lintas kendaraan yang berasal dari Bandung menuju Garut dan sebaliknya. Longsor yang terjadi pada Jalan Bandung-Tasik KM. 48 tidak hanya mengganggu lalu lintas kendaraan, tetapi juga membahayakan pengguna jalan dan keselamatan penduduk di Perumahan Cijolang. Pada penelitian ini, penanganan lereng dirancang dengan mengubah geometrik lereng atau trap lereng (alternatif 1) dan penggunaan struktur penahan tanah soldier pile (alternatif 2 ), yang memenuhi persyaratan faktor keamanan berdasarkan SNI 8460:2017. Perangkat lunak GeoStudio 2016 digunakan untuk menganalisis kestabilan lereng kondisi eksisting dan untuk kedua alternatif tersebut. Faktor keamanan lereng sebelum dilakukannya penanganan terhadap longsor 0,903 pada kondisi jenuh dan gempa. Berdasarkan hasil perancangan, penanganan alternatif 1 menghasilkan FK pada kondisi normal 1,724 dan FK pada kondisi gempa 1,163. Sedangkan, hasil perancangan alternatif 2 menghasilkan FK pada kondisi normal 1,658 dan FK pada kondisi gempa 1,102. Berdasarkan hasil perancangan kedua alternatif tersebut, diharapkan dapat diaplikasikan di lapangan sehingga lahan longsor dapat digunakan kembali untuk pembangunan Perumahan Cijolang.
\end{abstract}

Kata Kunci: Longsor, analisis stabilitas lereng, gempa bumi, geometrik lereng, soldier pile

\begin{abstract}
Landslides that occurred on the Cijolang housing estate, Limbangan District, Garut Regency after the M 4.9 earthquake resulted in the disruption of vehicle traffic flow from Bandung to Garut and vice versa. Landslide that occurred on Jalan Bandung-Tasik KM. 48 not only interfere with vehicle traffic, but also endanger road users and the safety of residents in Cijolang Housing. In this study, the slope reinforcement was designed by changing the slope geometry (alternative 1) and the use of soldier pile retaining structure (alternative 2), which met the safety factor requirements based on SNI 8460:2017. GeoStudio 2016 software is used to analyze slope stability for existing condition and both alternatives. The existing global safety factor is 0.903 in saturated and earthquake conditions. Based on the results of the design, alternative 1 produce global safety factor of 1.724 under normal conditions and 1.163 under earthquake conditions. Meanwhile, the results of alternative 2 design produce global safety factor of 1,658 under normal conditions and 1,102 under earthquake conditions. Based on the design result of the two alternatives, it is hoped that they can be applied in the field so that landslides can be reused for the construction of Cijolang Housing.
\end{abstract}

Keywords: Landslide, slope stability analysis, earthquake, slope geometric, soldier pile

\section{PENDAhuluan}

Infrastruktur jalan menjadi penggerak pertumbuhan ekonomi suatu bangsa. Berdasarkan alokasi pembiayaan publik dan swasta, infrastruktur dianggap sebagai lokomotif pembangunan nasional dan daerah [1,2]. Infrastruktur juga penting untuk meningkatkan kualitas hidup dan kesejahteraan manusia, diantaranya adalah peningkatan nilai konsumsi, produktivitas tenaga kerja, akses lapangan kerja, dan peningkatan kesejahteraan [1-3][6].

Longsor yang terjadi pada akses jalan nasional Bandung-Tasik KM. 48, Desa Cijolang, Kecamatan Limbangan, Kabupaten Garut pada hari Jumat, 21 Februari 2020 mengakibatkan terganggunya arus lalu lintas kendaraan yang berasal dari Bandung menuju Garut dan sebaliknya. Berdasarkan berita tersebut, insiden runtuhnya tembok penahan tanah terjadi sekitar pukul 08.00 WIB diduga dipicu oleh gempa bumi magnitudo 4,9 SR (BMKG) yang mengguncang Tasikmalaya [4].

Lokasi terjadinya longsor merupakan jalan arteri, kelas jalan III, dan termasuk jalan nasional yang menghubungkan Provinsi Jawa Barat dengan Provinsi Jawa Tengah. Jalan Bandung-Tasik adalah jalur pariwisata yang merupakan akses masuk beberapa objek wisata di Kabupaten Garut dan sekitarnya. Dampak longsor yang terjadi yaitu tertutupnya akses jalan utama menuju perumahan, mengikis lahan perumahan yang akan dibangun beberapa rumah, dan menurunnya daya beli di perumahan tersebut, 
serta menghindari terjadi longsoran yang suatu saat dapat menutup akses jalan utama di lokasi tersebut. Lokasi terjadinya longsor dan dokumentasi longsor yang terjadi dapat dilihat pada Gambar 1 dan Gambar 2.

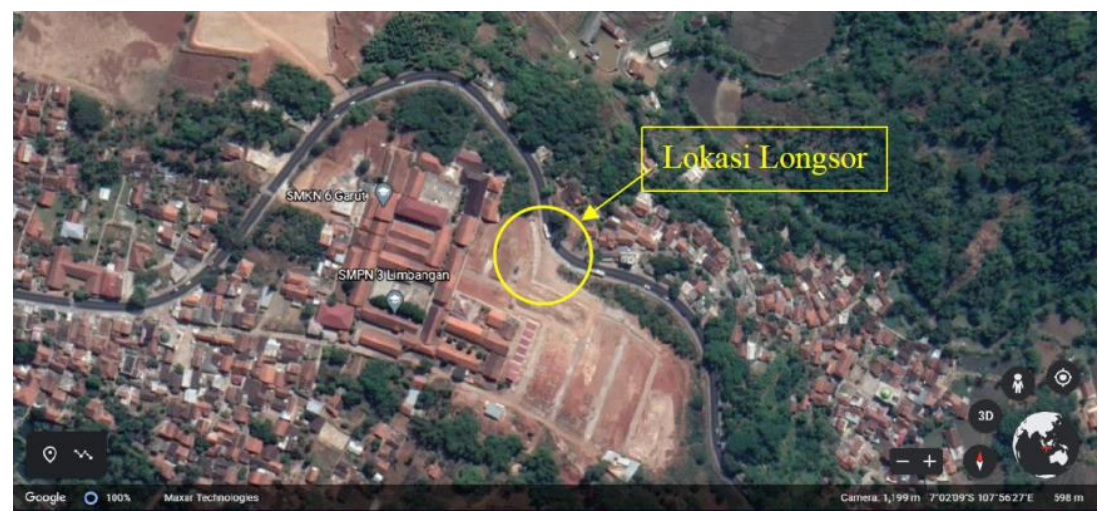

Gambar 1. Lokasi longsor di Jalan Bandung-Tasik KM. 48, Kabupaten Garut
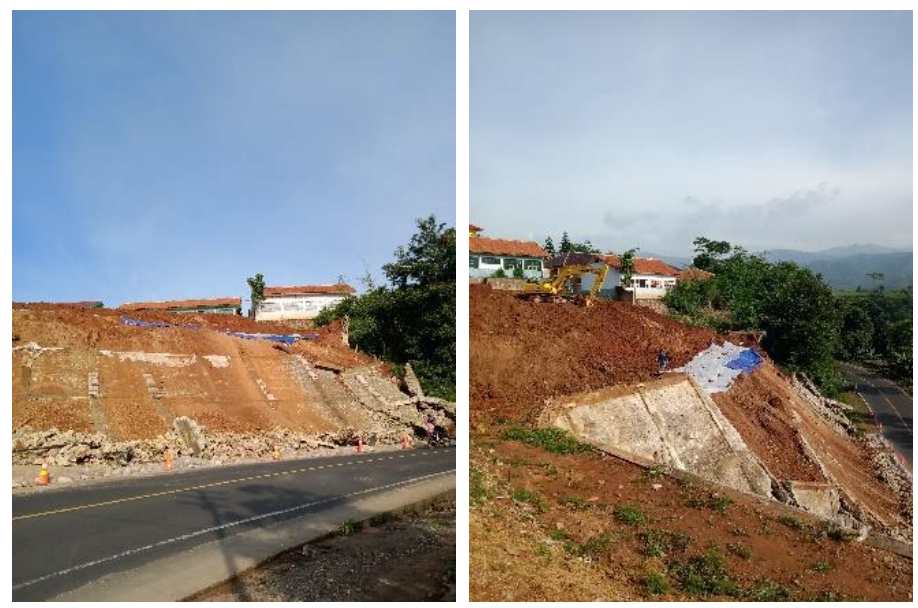

Gambar 2. Longsor yang terjadi setelah gempa 4,9 SR

Berdasarkan kejadian tersebut, perlu direncanakan alternatif penanganan lereng untuk mengantisipasi terjadinya longsor lanjutan. Pada penelitian ini, penanganan lereng dirancang dengan mengubah geometrik lereng atau trap lereng (alternatif 1) dan penggunaan struktur penahan tanah soldier pile (alternatif 2), yang memenuhi persyaratan faktor keamanan (FK) untuk lereng tanah berdasarkan SNI 8460:2017 [5] dengan mempertimbangkan stabilitas lereng akibat gempa, curah hujan, dan beban-beban yang bekerja di atasnya sebagai tindak lanjut dari kejadian tersebut.

\section{METODOLOGI PELAKSANAAN}

Metodologi penelitian dapat dilihat pada Gambar 3. Berdasarkan SNI 8460:2017 tentang Persyaratan perancangan geoteknik, faktor keamanan (FK) lereng yang direkomendasikan untuk analisis keamanan lereng tanah diperlihatkan pada Tabel 1 di bawah dengan didasarkan pada pertimbangan tingkat ketidakpastian kondisi analisis.

Tabel 1. Rekomendasi Faktor Keamanan (FK) lereng tanah [5]

\begin{tabular}{|l|c|c|}
\hline \multicolumn{1}{|c|}{ Biaya dan konsekuensi dari kegagalan lereng } & \multicolumn{2}{|c|}{$\begin{array}{c}\text { Tingkat ketidakpastian } \\
\text { kondisi analisis }\end{array}$} \\
\cline { 2 - 3 } & Rendah ${ }^{\text {a }}$ & Tinggi $^{\text {b }}$ \\
\hline $\begin{array}{l}\text { Biaya perbaikan sebanding dengan biaya tambahan } \\
\text { untuk merancang lereng yang lebih konservatif }\end{array}$ & 1,25 & 1,5 \\
\hline $\begin{array}{l}\text { Biaya perbaikan lebih besar dari biaya tambahan } \\
\text { untuk merancang lereng yang lebih konservatif }\end{array}$ & 1,5 & 2,0 atau lebih \\
\hline $\begin{array}{l}\text { a'Tingkat ketidakpastian kondisi analisis dikategorikan rendah, jika kondisi geologi dapat } \\
\text { dipahami, kondisi tanah seragam, penyelidikan tanah konsisten, lengkap dan logis } \\
\text { terhadap kondisi di lapangan. } \\
\text { bTingkat ketidakpastian kondisi analisis dikategorikan tinggi, jika kondisi geologi sangat } \\
\text { kompleks, kondisi tanah bervariasi, dan penyelidikan tanah tidak konsisten dan tidak dapat } \\
\text { diandalkan. }\end{array}$ \\
\hline
\end{tabular}



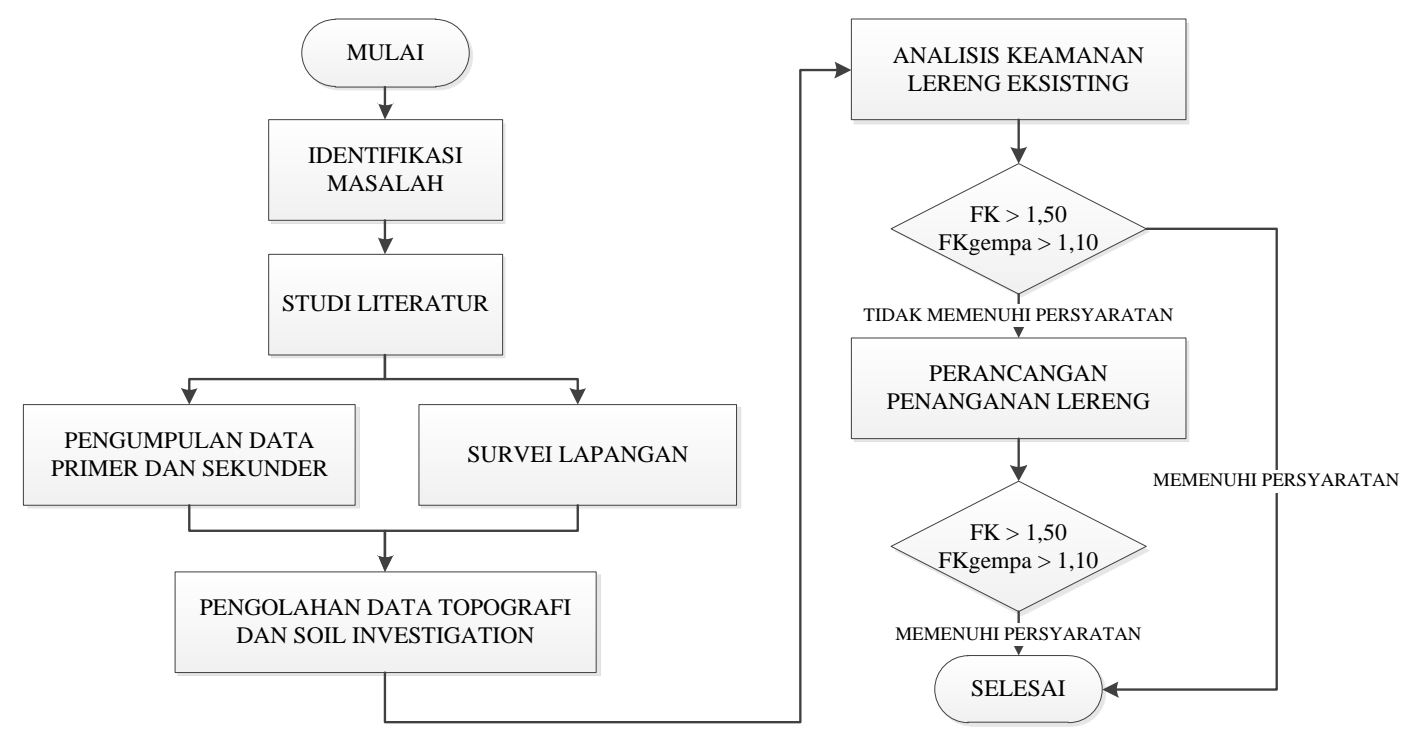

Gambar 3. Diagram alir penelitian

Pengaruh akibat beban gempa diperhitungkan jika lereng direncanakan pada area dekat pemukiman atau dengan kriteria kepentingan strategis yaitu tidak diperbolehkan mengalami keruntuhan atau putusnya jalur transportasi setelah terjadi gempa bumi [5]. Gempa rencana untuk lereng galian dan timbunan ditetapkan dengan kemungkinan terlewati besarannya selama umur rencana 50 tahun adalah $2 \%$ atau setara dengan periode ulang 50 tahun dengan mengacu pada peta gempa yang terdapat pada surat edaran Menteri Pekerjaan Umum No. 12/SE/M/2010 [5][8-12].

Faktor keamanan (FK) minimum yang digunakan pada analisis model pseudo-statik disyaratkan lebih besar dari 1,10 $(\mathrm{FK}>1,10)$ berdasarkan koefisien seismik yang diperoleh dari percepatan puncak di permukaan (PGA) dengan penentuan kelas situs dan faktor amplifikasi [5].

\section{HASIL DAN PEMBAHASAN}

\subsection{Hasil Penyelidikan Tanah dan Topografi}

Penyelidikan di lapangan dan di laboratorium dilakukan untuk mengetahui kondisi stratifikasi tanah, sifat fisik serta sifat mekanik lapisan-lapisan tanah di lokasi tinjauan, untuk selanjutnya dimodelkan dalam Geostudio 2016. Gambar 4 di bawah merupakan denah hasil pengujian lapangan (cone penetration test dan pengeboran tangan).

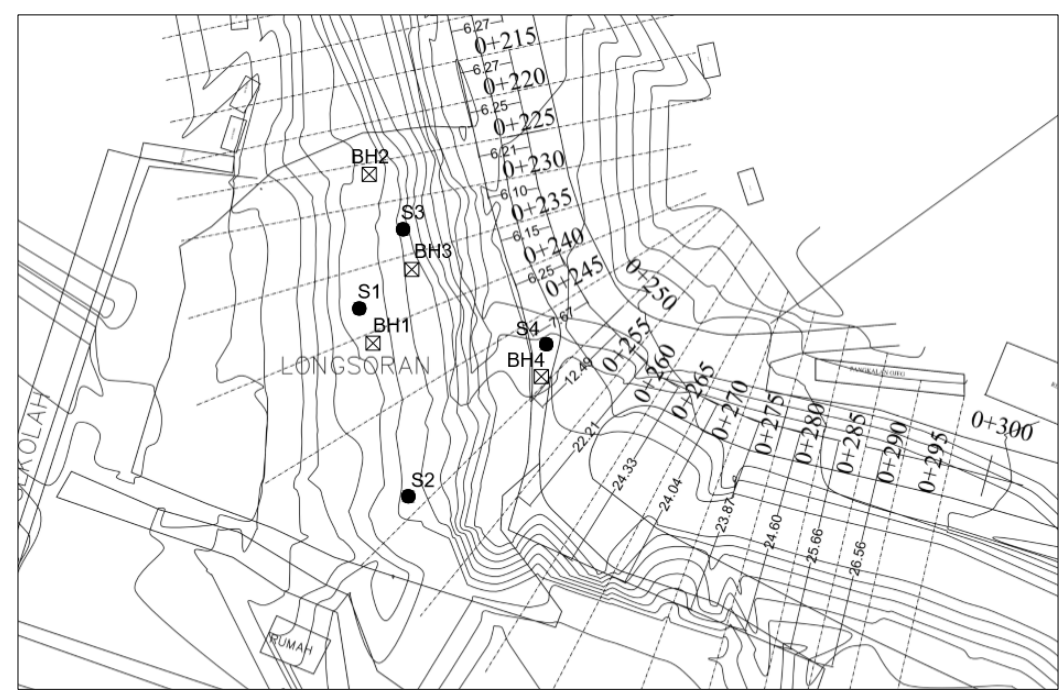

Gambar 4. Lokasi titik pengujian tanah di lapangan

Berdasarkan pengujian sondir yang dilakukan di lapangan, diperoleh hasil perkiraan jenis tanah. Hasil pengujian Cone Penetration Test (CPT) dapat dilihat pada Tabel 2, Tabel 3, Tabel 4, dan Tabel 5. Selain pengujian CPT, didapatkan juga datadata tanah yang digunakan sebagai parameter desain penanganan longsor pada Jalan Bandung-Tasik KM. 48, Limbangan, Kabupaten Garut. Parameter tanah untuk setiap lapisan tanah diketahui melalui pengujian tanah yang dilakukan di laboratorium terhadap sampel boring tanah seperti pada Tabel 6. 
Tabel 2. Hasil pengujian CPT $S-1$

\begin{tabular}{ccc}
\hline Kedalaman $(\mathrm{m})$ & $\mathrm{qc}\left(\mathrm{kg} / \mathrm{cm}^{2}\right)$ & Perkiraan Jenis Tanah \\
\hline $0,2-4$ & 12 & Lempung \\
\hline $4,2-5$ & 42 & Lempung Kelanauan \\
\hline $5,2-6$ & 46 & Pasir Kelanauan \\
\hline $6,2-7$ & 50 & Lempung \\
\hline $7,2-9$ & 56 & Lempung Kelanauan \\
\hline $9,2-10$ & 60 & Pasir \\
\hline $10,2-11,6$ & 100 & Lempung \\
\hline
\end{tabular}

Tabel 4. Hasil pengujian CPT S-3

\begin{tabular}{ccc}
\hline Kedalaman $(\mathrm{m})$ & $\mathrm{qc}\left(\mathrm{kg} / \mathrm{cm}^{2}\right)$ & Perkiraan Jenis Tanah \\
\hline $0,2-2$ & 16 & Lempung \\
\hline $2,2-3$ & 20 & Lempung Kelanauan \\
\hline $3,2-7$ & 45 & Lempung \\
\hline $7,2-8$ & 80 & Lempung Kelanauan \\
\hline $8,2-9,8$ & 105 & Pasir \\
\hline
\end{tabular}

Tabel 3. Hasil pengujian CPT S-2

\begin{tabular}{ccc}
\hline Kedalaman $(\mathrm{m})$ & $\mathrm{qc}\left(\mathrm{kg} / \mathrm{cm}^{2}\right)$ & Perkiraan Jenis Tanah \\
\hline $0,2-1$ & 16 & Lempung \\
\hline $1,2-3$ & 70 & Pasir \\
\hline $3,2-4$ & 90 & Pasir Kelanauan \\
\hline $4,2-5$ & 80 & Lempung Kelanauan \\
\hline $5,2-7$ & 90 & Lempung \\
\hline $7,2-7,4$ & 150 & Pasir \\
\hline
\end{tabular}

Tabel 5. Hasil pengujian CPT S-4

\begin{tabular}{ccc}
\hline Kedalaman $(\mathrm{m})$ & $\mathrm{qc}\left(\mathrm{kg} / \mathrm{cm}^{2}\right)$ & Perkiraan Jenis Tanah \\
\hline $0,2-1$ & 32 & Lempung Kelanauan \\
\hline $1,2-2$ & 18 & Lempung \\
\hline $2,2-3,6$ & 200 & Pasir \\
\hline
\end{tabular}

Tabel 6. Hasil pengujian tanah di laboratorium

\begin{tabular}{cccccc}
\hline \multirow{2}{*}{$\begin{array}{c}\text { Parameter } \\
\text { Tanah }\end{array}$} & Satuan & Lapisan 1 & Lapisan 2 & Lapisan 3 & Lapisan 4 \\
\cline { 3 - 6 } & Lempung & $\begin{array}{c}\text { Lempung } \\
\text { Kelanauan }\end{array}$ & Lempung & Tanah Keras \\
\hline Kohesi (c) & $\mathrm{kPa}$ & 19,42 & 21 & 30 & 49,033 \\
\hline$\theta$ & $\circ$ & 20 & 25 & 20 & 35 \\
\hline $\begin{array}{c}\text { Unit } \\
\text { Weight }\end{array}$ & $\mathrm{kN} / \mathrm{m}^{3}$ & 15,691 & 15,691 & 16,230 & 16,582 \\
\hline
\end{tabular}

Survei topografi di lokasi tinjauan meliputi pengukuran dengan menggunakan theodolite dan drone yang menghasilkan elevasi permukaan tanah serta garis-garis kontur. Hasil dari pengukuran tersebut akan memberikan kontur dan potongan kritis lereng dapat dilihat pada Gambar 5 dan Gambar 6.
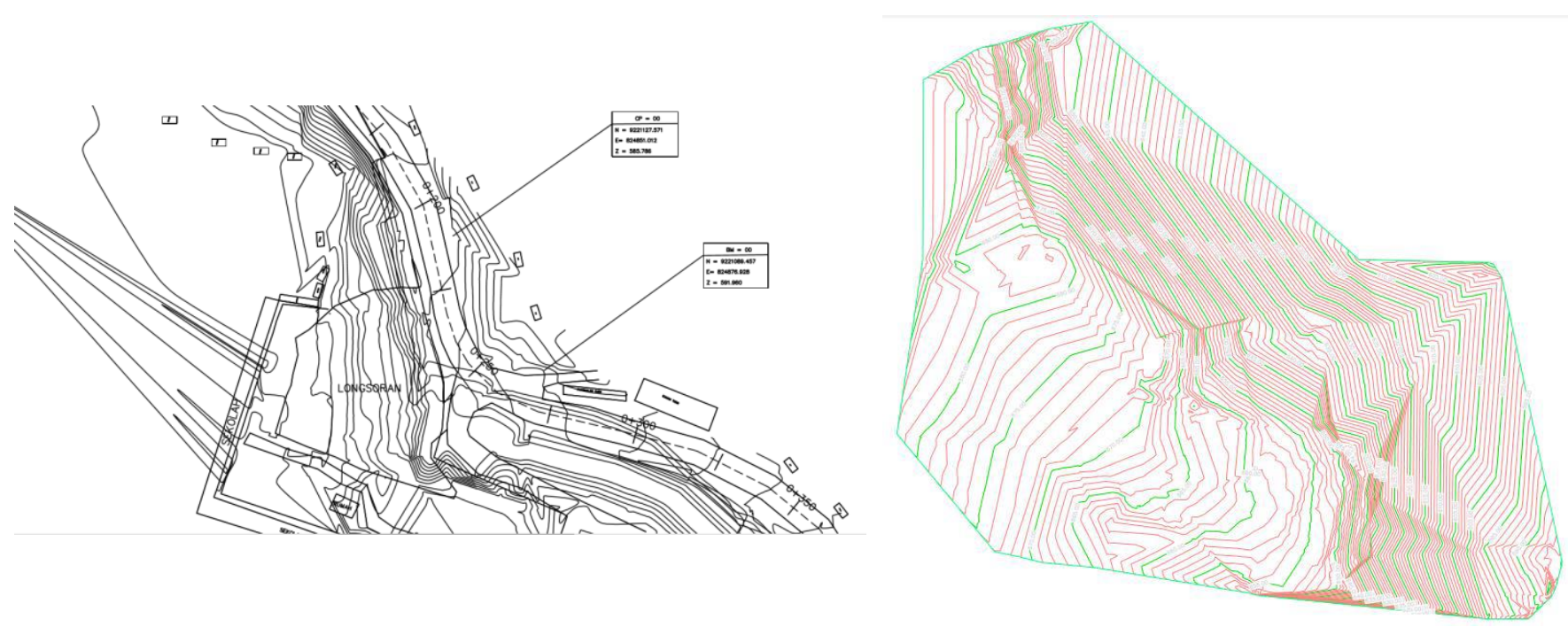

Gambar 5. Kontur lokasi tinjauan menggunakan theodolite dan drone 


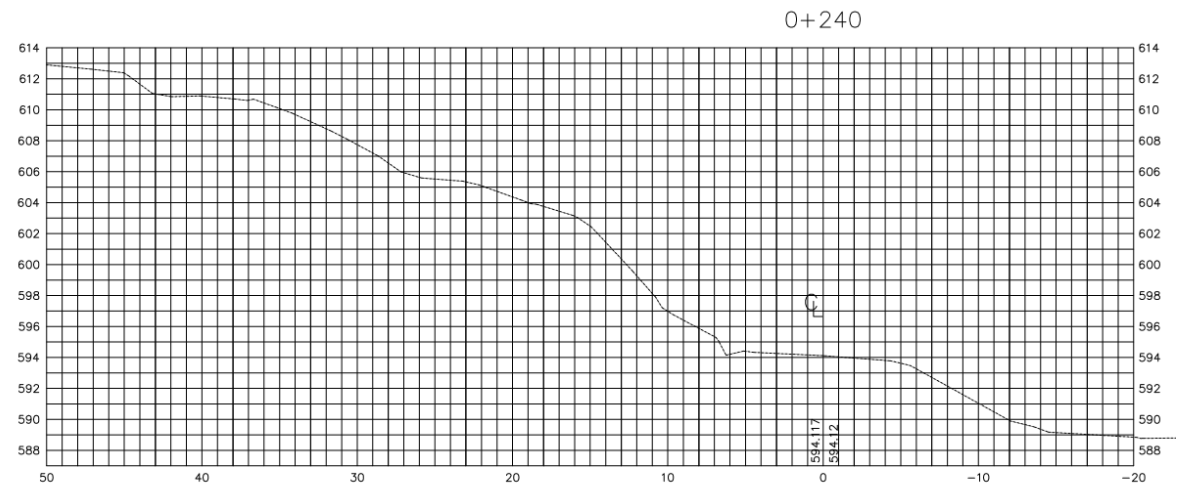

Gambar 6. Potongan lereng

\subsection{Analisis Keamanan Lereng Eksisting setelah Longsor}

Berdasarkan hasil penyelidikan tanah dan survei topografi diperoleh stratigrafi tanah untuk pemodelan analisis keamanan lereng, dapat dilihat pada Gambar 7. Analisis keamanan lereng biasanya dilakukan dengan pendekatan kesetimbangan batas (limit equilibrium), teori batas plastis, dan metode numerikal seperti metode elemen hingga (finite element method). Dengan pendekatan limit equilibrium, pelapisan tanah dimodelkan secara sederhana dan tidak dapat memodelkan tahapan konstruksi (stage construction), sedangkan pada finite element method, pemodelan stratifikasi lereng dapat dilakukan secara lebih kompleks dan dapat memodelkan tahapan konstruksi [5][8-12]. Pada penelitian ini akan digunakan perangkat lunak dengan pendekatan kesetimbangan batas, yaitu Geostudio Slope/W 2016 untuk analisis kondisi eksisting dan perancangan penanganan lereng.

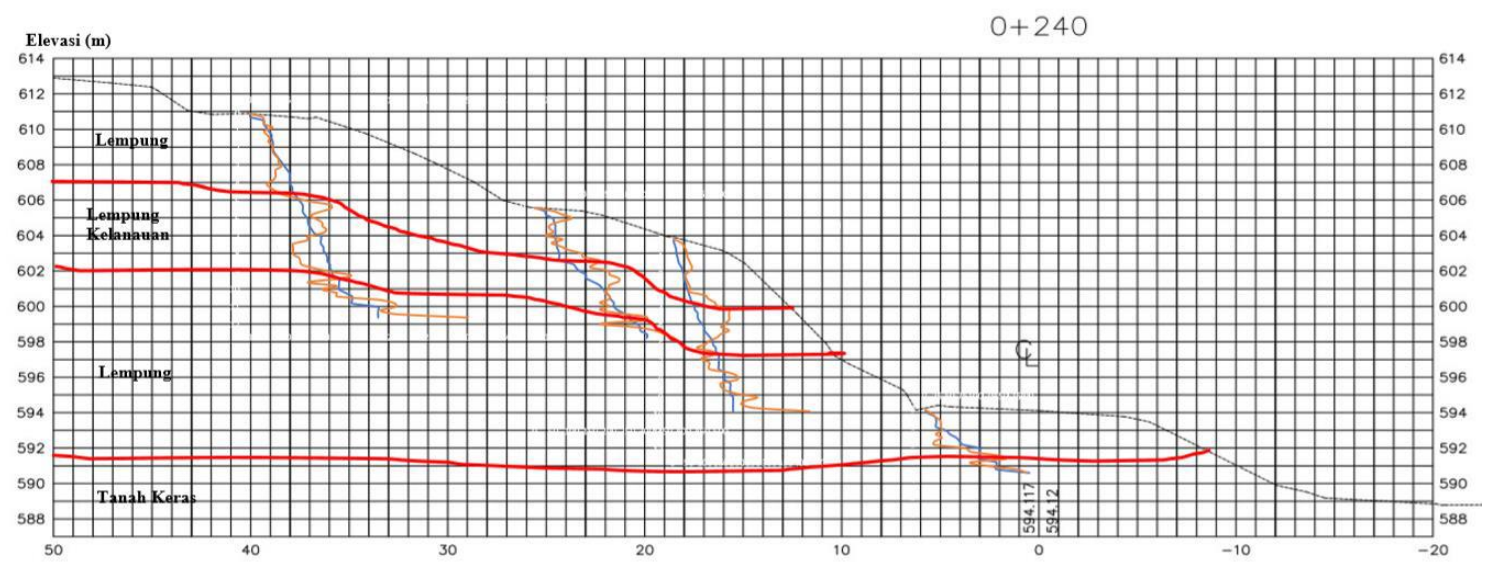

Gambar 7. Stratigrafi tanah pada kontur setelah terjadi longsor

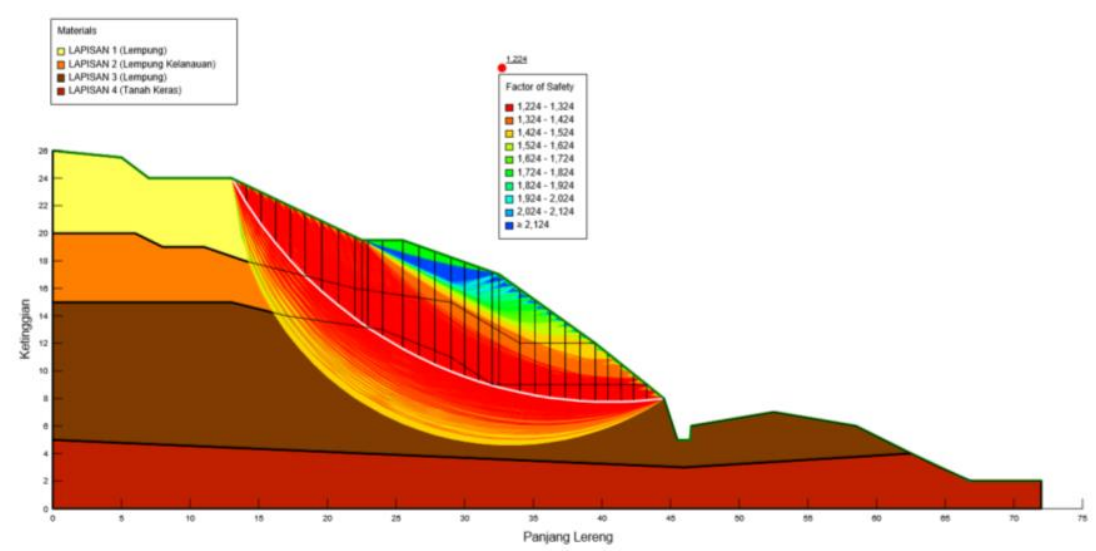

Gambar 8. Analisis keamanan lereng eksisting setelah terjadi longsor

Berdasarkan hasil analisis keamanan lereng eksisting setelah longsor (Gambar 8) didapatkan FK = 1,224 pada kondisi gempa. Lereng eksisting pada kondisi setelah longsor sudah memenuhi persyaratan berdasarkan SNI 8460:2017 (FK > 1,10), namun untuk merencanakan ulang perbaikan lereng, penulis melakukan rekonstruksi lereng berdasarkan geometri sebelum terjadinya longsor. 


\subsection{Analisis Stabilitas Lereng Eksisting}

Setelah menganalisis stabilitas lereng eksisting pasca longsor, dilakukan analisis stabilitas lereng hasil rekonstruksi untuk mendapatkan model longsor yang terjadi di lapangan. Beban yang diaplikasikan pada model adalah beban minimal sebesar $10 \mathrm{kPa}$. Nilai koefisien gempa ditentukan dari percepatan puncak Peak Ground Acceleration (PGA). Nilai PGA diperoleh dengan memasukkan koordinat lokasi lereng pada http://puskim.pu.go.id/Aplikasi/desain_spektra_indonesia_2011/ [7]. Didapat nilai PGA sebesar 0,456 , sehingga koefisien gempa dapat dihitung dengan rumus sebagai berikut.

$\mathrm{k}_{\mathrm{h}}=\frac{1}{2} \times \mathrm{PGA}=\frac{1}{2} \times 0,456=0,228$

$\mathrm{k}_{\mathrm{v}}=\frac{1}{10} \times \mathrm{PGA}=\frac{1}{10} \times 0,456=0,046$

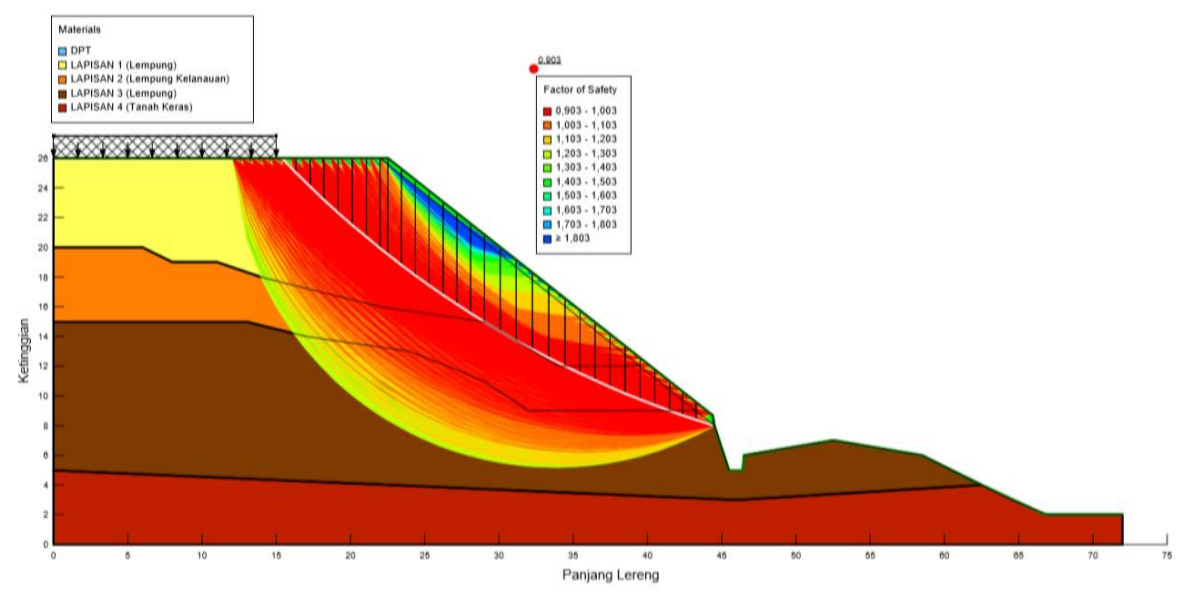

Gambar 9. Analisis Stabilitas Lereng Kondisi Jenuh dan Gempa.

Berdasarkan hasil analisis stabilitas lereng setelah direkonstruksi pada kondisi jenuh dan gempa (Gambar 9) diperoleh faktor keamanan FK = 0,903. Hasil yang diperoleh lebih kecil dari nilai faktor keamanan yang direkomendasikan pada SNI 8460:2017, sehingga diperlukan penanganan agar infrastruktur jalan dapat berfungsi secara normal. Pada penelitian ini dirancang dua alternatif penanganan longsor. Hasil FK beberapa kondisi analisis, dapat dilihat pada Tabel 7.

Tabel 7. Hasil FK eksisting pada berbagai kondisi.

\begin{tabular}{ccc}
\hline Kondisi & FK & Rekomendasi FK [5] \\
\hline Normal & 1,327 & 1,50 \\
\hline Jenuh (Hujan) & 1,304 & 1,50 \\
\hline Normal dan Gempa & 0,920 & 1,10 \\
\hline Jenuh dan gempa*) & 0,903 & 1,100 \\
\hline
\end{tabular}

*) Kondisi sewaktu terjadi longsor Februari 2020

\subsection{Perencanaan Penanganan Lereng}

\subsubsection{Perencanaan Geometrik dengan Trap Lereng (Alternatif 1)}

Penanganan dengan melakukan perubahan geometrik dengan trap lereng diterapkan pada kasus ini. Selain mengubah geometrik lereng, dilakukan juga perencanaan drainase lereng dan memberi rumput vetiver dengan jarak antar rumput 0,5 meter di lereng tersebut. Dimensi trap lereng dapat dilihat pada Gambar 10.

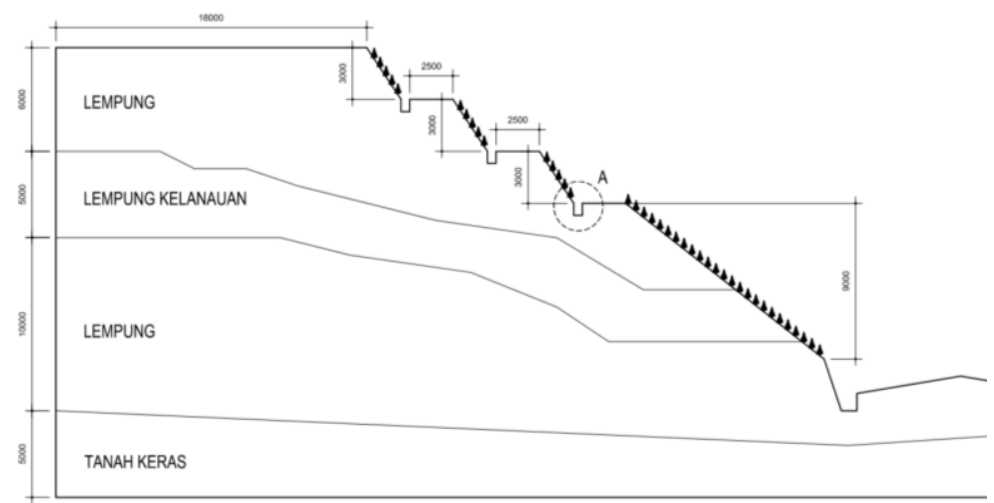

Gambar 10. Alternatif penanganan lereng dengan mengubah geometri lereng 
Hasil analisis perencanaan penanganan dengan mengubah geometrik dengan trap lereng, dapat dilihat pada Gambar 6.

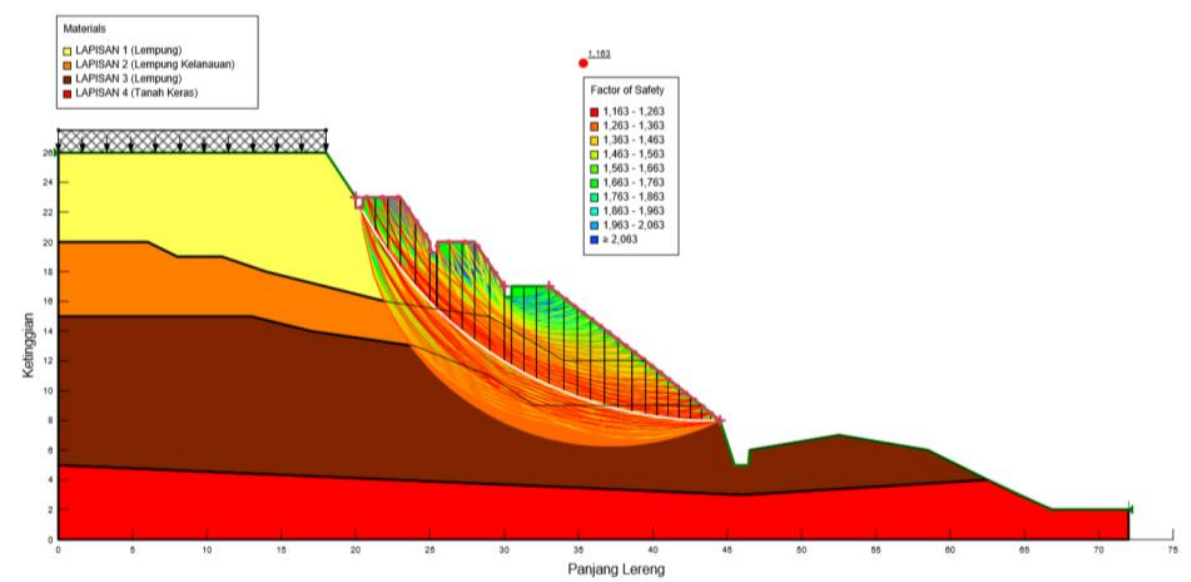

Gambar 11. Hasil analisis keamanan perencanaan geometrik lereng beserta adanya drainase

Dengan perubahan geometrik beserta adanya drainase seperti pada Gambar 11 didapat faktor keamanan FK=1,163 pada kondisi jenuh dan gempa. Penanganan lereng telah memenuhi persyaratan berdasarkan SNI 8460:2017, sehingga penanganan dapat diterima. Faktor keamanan FK hasil analisis stabilitas lereng setelah penanganan dengan mengubah geometrik lereng dengna kondisi-kondisi analisis, dapat dilihat pada Tabel 8.

\begin{tabular}{|c|c|c|}
\hline Kondisi & FK & Rekomendasi FK [5] \\
\hline Normal & 1,724 & 1,50 \\
\hline Jenuh (Hujan) & 1,692 & 1,50 \\
\hline Normal dan Gempa & 1,186 & 1,10 \\
\hline Jenuh dan gempa & 1,163 & 1,10 \\
\hline
\end{tabular}

\subsubsection{Perencanaan Soldier Pile (Alternatif 2)}

Penanganan dengan melakukan perencanaan soldier pile merupakan alternatif kedua yang diterapkan pada kasus ini. Selain adanya soldier pile, penulis juga melakukan perencanaan drainase lereng seperti pada perencanaan alternatif 1 dan memberi rumput vetiver di lereng tersebut. Soldier pile yang digunakan berdiameter 0,3 meter dengan kedalaman 15 meter. Hasil analisis perencanaan penanganan dengan menggunakan soldier pile, dapat dilihat pada Gambar 12.

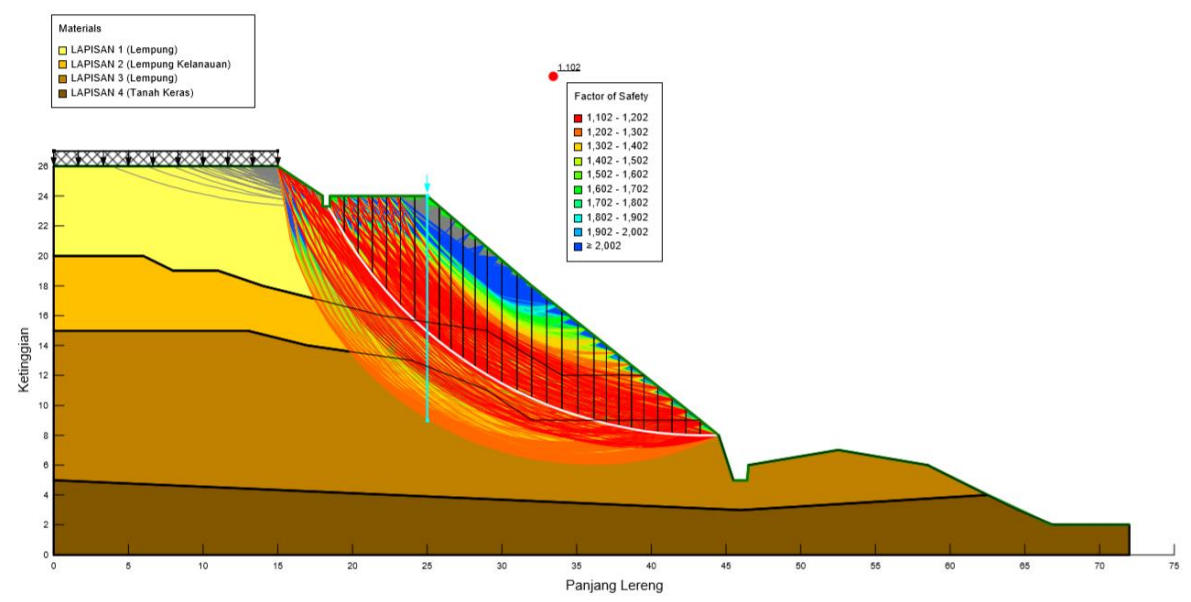

Gambar 10. Hasil Analisis Perencanaan Penanganan dengan Soldier Pile.

Dengan adanya soldier pile sedalam 15 meter seperti pada Gambar 12 didapatkan faktor keamanan FK = 1,102 pada kondisi jenuh dan gempa. Berdasarkan hasil probabilitas atau modus yang didapat yaitu faktor keamanan FK di antara 1,2 - 1,3. Faktor keamanan tersebut lebih besar dari 1,10. Sehingga lereng tersebut memenuhi persyaratan dapat dikategorikan aman terhadap gempa. Faktor keamanan FK hasil analisis stabilitas lereng setelah penanganan dengan menggunakan soldier pile di berbagai kondisi, dapat dilihat pada Tabel 9. 
Tabel 9. Nilai FK alternatif 2 perencanaan penanganan dengan soldier pile pada berbagai kondisi

\begin{tabular}{ccc}
\hline Kondisi & FK & Rekomendasi FK [5] \\
\hline Normal & 1,658 & 1,50 \\
\hline Jenuh (Hujan) & 1,623 & 1,50 \\
\hline Normal dan Gempa & 1,125 & 1,10 \\
\hline Jenuh dan gempa & 1,102 & 1,10 \\
\hline
\end{tabular}

\section{KESIMPULAN}

Berdasarkan hasil analisis menggunakan GeoStudio Slope W/ 2016, terdapat dua alternatif yang dihasilkan sebagai pilihan penanganan longsor di Jalan Bandung-Tasik KM 48, Kecamatan Limbangan, Kabupaten Garut. Perbandingan faktor keamanan kedua alternatif penanganan pada berbagai kondisi dapat dilihat pada Tabel 10.

Tabel 10. Resume hasil analisis keamanan

\begin{tabular}{cccc}
\hline \multirow{2}{*}{ Kondisi } & \multicolumn{3}{c}{ Faktor keamanan (FK) } \\
\cline { 2 - 4 } & $\begin{array}{c}\text { Kondisi } \\
\text { Eksisting }\end{array}$ & Alternatif 1 & Alternatif 2 \\
\hline Normal & 1,327 & 1,724 & 1,658 \\
\hline Jenuh (hujan) & 1,304 & 1,692 & 1,623 \\
\hline Normal dan Gempa & 0,920 & 1,186 & 1,125 \\
\hline Jenuh dan Gempa & 0,903 & 1,163 & 1,102 \\
\hline
\end{tabular}

Dari hasil analisis, kedua alternatif dapat dipilih disesuaikan dengan kebutuhan dan ketersediaan lahan di lapangan dengan tetap memperhatikan persyaratan desain dan hitungan

\section{ACKNOWLEDGMENT}

Penulis mengucapkan terima kasih terhadap semua dukungan dan fasilitas dari Jurusan Teknik Sipil dan Kelompok Keahlian Bidang Geoteknik Politeknik Negeri Bandung.

\section{REFERENCES}

[1] Haris A 2005 Pengaruh Penatagunaan Tanah Terhadap Keberhasilan Pembangunan Infrastruktur dan Ekonomi Direktorat Tata Ruang dan Pertahanan, Bappenas

[2] Sukwika T 2018 Peran Pembangunan Infrastruktur Terhadap Ketimpangan Ekonomi Antarwilayah di Indonesia Jurnal Wilayah dan Lingkungan 6(2) 115-130

[3] Atmaja H K and Mahalli Kasyful 2015 Pengaruh Peningkatan Infrastruktur Terhadap Pertumbuhan Ekonomi di Kota Sibolga Jurnal Ekonomi dan Keuangan 3(4)

[4] H Ghani 2020 Dampak Gempa Tasik, Tembok Penahan Tanah Perumahan di Garut Runtuh Detiknews. Tersedia: https://news.detik.com/berita-jawa-barat/d-4908441/dampak-gempa-tasik-tembok-penahan-tanah-perumahan-di-garut-runtuh

[5] SNI 8460:2017 2017 Persyaratan Perancangan Geoteknik Badan Standardisasi Nasional

[6] H Hendry, A K Somantri, A Febriansya, and M D Nurhadi 2020 IOP Conf. Ser.: Mater. Sci. Eng. 732012027

[7] Pusat Penelitian dan Pengembangan Permukiman 2011 Desain Spektra Indonesia. Tersedia: http://puskim.pu.go.id/Aplikasi/desain_spektra_indonesia_2011/

[8] B M Das 1992 Principles of Soil Dynamics. United States of America: PWS-KENT.

[9] B M Das 1993 Mekanika Tanah (Prinsip-Prinsip Rekayasa Geoteknis) Jilid 2. Surabaya: ITS.

[10] H C Hardiyatmo 1996 Teknik Fondasi 1. Jakarta: PT. Gramedia Pustaka Utama.

[11] H C Hardiyatmo 2003 Mekanika Tanah II Edisi 3. Yogyakarta: Gadjah Mada University Press.

[12] M A Bahtiar, N S Surjandar and Setiono 2016 Korelasi Nilai Kohesi dan Sudut Geser Dalam Dengan Nilai Tahanan Konus Sondir Menggunakan Metode Statistika. Jurnal Matriks Teknik Sipil, 690-698.

[13] Hariish 2013 Perancangan Paku Tanah (Soil Nailing) dan Mengubah Geometrik Lereng Pada Penanganan Kelongsoran Cadas Pangeran KM. 36+650. Bandung: Politeknik Negeri Bandung.

[14] K Nakazawa and S Sosrodarsono 2000 Soil Mechanics and Foundation Engineering Jakarta: PT. Pertja.

[15] B Widjaja 2004 Analisis Batas Untuk Kestabilan Lereng. Jurnal Ilmiah, 1-11.

[16] Z Zakaria 2009 Analisis Kestabilan Lereng. Bandung: Universitas Padjadjaran. 